\title{
Evaluation of Customers' Sustainable Fashion Perception
}

\author{
Vida Davidavičienè ${ }^{1}$, Jurgita Raudeliūnienè ${ }^{2}$ (corresponding author), \\ Margaryta Zubrii ${ }^{3}$ \\ 1,2,3 Department of Business Technologies and Enterpreneurship, Faculty of \\ Business Management, Vilnius Gediminas Technical University, Sauletekio \\ al.11, 10223, Vilnius, Lithuania \\ ${ }^{1}$ vida.davidaviciene@vgtu.lt; ${ }^{2}$ jurgita.raudeliuniene@vgtu.lt; ${ }^{3}$ margaryta.zubrii@stud.vgtu.lt
}

\begin{abstract}
Globalization, technological development and the associated transformation processes have both positive and negative effects not only on fashion industry organizations and their customers, but also on the global environmental protection. Positive transformation changes are associated with the ability of fashion organizations to satisfy changing needs of both mass and individual consumers in a dynamic environment that creates the conditions for creating mutual value, for organizations to create uniqueness and leadership in the global market. However, the constant satisfaction of changing consumers' needs and the creation of new ones, the lack of corporate social responsibility of fashion organizations and irresponsible consumer behaviour are prerequisites for environmental problems. An important aspect of addressing the identified issues is customers' sustainable fashion perception, which creates the conditions not only for changing consumers understanding about sustainable fashion and after all their behaviour, but also for fashion sector organizations to take social responsibility for their activities. Therefore, this research aims to evaluate the customers' sustainable fashion perception in Lithuania and its features. To reach the goal of the study such research methods as scientific literature review, survey (structured questionnaire), and multiple criteria assessment method were applied. The findings of study show that information about environmental load of each product, fair trade and recycling are the main features of sustainable fashion.
\end{abstract}


Keywords: fashion, sustainable fashion, fashion consumption, fashion perception, customers' sustainable fashion perception.

\section{Introduction}

Globalization, technological advancements, and the resulting transformation processes have had both positive and negative changes for fashion sector organizations and society (Davidavičienè, Davidavičius, and Tamošiūnienè, 2019). The lack of corporate social responsibility of fashion sector organizations and irresponsible consumer behavior has created the preconditions for scientific studies on the environmental issues caused by fashion sector and such research objects as effect of ethical leadership and corporate social responsibility on organization performance, corporate social (ir)responsibility in the textile sector, the need for sustainability in the fashion sector, customers' sustainable fashion perception, customers' behaviour change in the textile sector were analysed (Ashworth, 2012; Lueg, Pedersen, and Clemmensen, 2015; Garcia-Torres, ReyGarcia, and Albareda-Vivo, 2017; Luque and Herrero-Garcia, 2019). Accordingly, in recent years such research objects as "sustainability in the fashion", "sustainable fashion", "customers' sustainable fashion perception" causes multiple debates among scientists, fashion business practitioners and environmental activists. On the one hand, this type of scientific discussion created the conditions for raising serious problems, recognizing and studying them in depth that has influenced positive developments in the fashion sector. On the other hand, a variety of different approaches to sustainable fashion by scientists and business practitioners has not fully integrated the practical value of sustainable fashion perception for the final consumer. Also, over time, consumers' perception of sustainable fashion has changed and such terms as "eco-fashion" and "ethical fashion" gained wider recognition. Therefore, it is important to evaluate how the rise of a particular niche of sustainable fashion (recycling, second-hand, Fairtrade items, organic clothing, and so on) on the market influenced sales and consumers' perception of the issue.

Therefore, this research aims to evaluate the customers' sustainable fashion perception in the case of Lithuania and its features. The main tasks of the research are to determine the concept of sustainable fashion, define factors affecting consumers' perception of sustainable fashion, select research methods for an evaluation of consumers' perception of sustainable fashion features, and define the relations between consumers' perception and features of sustainable fashion consumption. To reach the goal and the main tasks of the study such research methods as scientific literature review, survey (structured questionnaire), and multiple criteria assessment method were applied. 
The findings of study show that the level of interest in sustainable fashion and willingness to pay more for it is higher in Lithuania. However, the perception of sustainable fashion in Lithuania differs from the rest of Europe. Lithuanian customers have highly evaluated the following sustainable fashion features: information about an environmental load of a garment, fair trade, and recycling.

\section{Literature Review}

During the decades of research, the research object of sustainability in the fashion industry has been explored from different perspectives and was segmented into more concrete fields of emphasis: business management, textile sourcing and production, branding and marketing, sustainable design, studies of consumers' behaviour.

The concept of sustainable fashion is in the textile industry, it is related to less harmful processes and organic production, as well as fair wages and safe working places for employees. Recycling is also an important part of the sustainable textile industry. In design field sustainability is associated with more efficient use of materials, less textile consumption and less waste production, zero waste design approaches, also an implementation of technologies into all steps to fasten the process and improve the quality of the product. Often sustainable fashion designers work with the up-cycling method creating a garment from pre- and post-consumer textile waste. In studies of fashion's supply chain, it is based not only on efficient uses of planet resources (energy and water), but also human resources. In market studies sustainability has an educational role, analysing patterns of consumption behaviour, possibilities to inform customers about the effects of their consumption.

Scientists and business practitioners differently describe sustainable fashion concept. Sustainable fashion can be defined as eco-designed fashion products (Wagner, Curteza, Hong, Chen, Thomassey, and Zeng, 2019), a slow fashion (Gupta, Gwozdz, and Gentry, 2019), a long-term (McIntyre, 2019) relationship with clothing and a capacity to be ethical (Clarke and Holt, 2016), an environmentally responsible behaviour (Geiger and Keller, 2018) when buying and wearing clothing (Clarke and Holt, 2016), a sustainable clothing consumption practice (Didd and Yan, 2019) that can improve sustainable apparel consumption (Gupta, Gwozdz, and Gentry, 2019) in terms of environment-friendly appearance (Wagner, Curteza, Hong, Chen, Thomassey, and Zeng, 2019) (Table 1).

If the previous research on sustainable fashion was centred on textile and clothing production operations and fast fashion influence on markets, recent studies pay attention to consumption behaviour of a modern consumer and on 
how to inform the consumer about the effects of different consumption patterns (Karimi, Ahmad, Akbar, and Davidavičienè, 2018). Sustainable fashion consumption includes various areas such as manufacture, transportation, retail, use, and disposal of clothing (McNeill and Venter, 2019).

Table 1: Sustainable fashion views (created by the authors)

\begin{tabular}{|c|c|}
\hline Author(s), year & Scientists' viewpoint \\
\hline $\begin{array}{l}\text { Clarke and Holt, } \\
2016\end{array}$ & $\begin{array}{l}\text { Relationships with clothing, the capacity to be ethical when buying } \\
\text { and wearing clothing. }\end{array}$ \\
\hline $\begin{array}{l}\text { Geiger and } \\
\text { Keller, } \\
2018\end{array}$ & $\begin{array}{l}\text { Environmentally responsible behaviour with positive relation of } \\
\text { biospheric and altruistic values. }\end{array}$ \\
\hline $\begin{array}{l}\text { Athwal, Wells, } \\
\text { Carrigan, and } \\
\text { Henninger, } 2019\end{array}$ & $\begin{array}{l}\text { Three core themes are consumer concerns and practices, } \\
\text { organizational concerns and practices, and international and cross- } \\
\text { cultural issues. }\end{array}$ \\
\hline $\begin{array}{l}\text { Didd and Yan, } \\
2019\end{array}$ & $\begin{array}{l}\text { Clothing repair and community mending events are a part of } \\
\text { sustainable clothing consumption practices. }\end{array}$ \\
\hline $\begin{array}{l}\text { Gupta, Gwozdz, } \\
\text { and Gentry, } 2019\end{array}$ & Slow fashion that can improve sustainable apparel consumption. \\
\hline $\begin{array}{l}\text { Hedegård, } \\
\text { Gustafsson, } \\
\text { and Paras, } 2019\end{array}$ & $\begin{array}{l}\text { Reuse is one of the common suggested strategies to render fashion } \\
\text { retail sustainable. }\end{array}$ \\
\hline McIntyre, 2019 & $\begin{array}{l}\text { Emotional attachments that inform the long-term relationships } \\
\text { with one's wardrobe. }\end{array}$ \\
\hline $\begin{array}{l}\text { McKeown and } \\
\text { Shearer, } 2019\end{array}$ & $\begin{array}{l}\text { The sustainable fashion concept raised on the negative } \\
\text { environmental impact of fashion, and awareness of sustainability } \\
\text { issues. }\end{array}$ \\
\hline $\begin{array}{l}\text { McNeill and } \\
\text { Venter, } \\
2019\end{array}$ & $\begin{array}{l}\text { Represented by four alternative forms of consumption: renting, } \\
\text { borrowing, swapping and purchasing second - hand. }\end{array}$ \\
\hline $\begin{array}{l}\text { Wagner, Curteza, } \\
\text { Hong, Chen, } \\
\text { Thomassey, and } \\
\text { Zeng, } 2019\end{array}$ & $\begin{array}{l}\text { Eco-designed fashion products with distinctive style in terms of } \\
\text { environment-friendly appearance. }\end{array}$ \\
\hline
\end{tabular}

Many empirical studies show that consumers generally have a positive 
attitude to sustainable fashion, however, that does not often reflect in their purchase decisions (Shaw and Riach, 2011; Goworek, Fisher, Cooper, Woodward, and Hiller, 2012; Perez and Lonsdale, 2018; McNeill and Venter, 2019). Younger consumers often present less knowledge on the issues of sustainability, their consumption behaviour is usually less sustainable as they tend to change clothing more often regarding their taste and changes of fashion, rather than actual needs (Perez and Lonsdale, 2018). It is suggested that improvements in labelling and providing more information about the garment, its sustainability features, to the consumer affect purchase decisions and consumption of clothing. Perez and Lonsdale (2018) suggest that a brand's communication with younger customers generation should be clear and accessible (for example, through providing information using labels with minimal design and clear instructions on care). On the other hand, packaging can be designed to be multifunctional and have further life-span after the purchase of a garment. Also, collaborative consumption is expected to gain more social impact in the future. Young women perceive collaborative fashion consumption as a way to express individual identity, while social and ethical aspects are less motivating for such behaviour (McNeill and Venter, 2019).

In scientific literature variety of consumers' perception aspects of sustainable fashion were analysed: combination of factors influencing product purchase decision (individual and massive needs, fit, colour, quality, multifunctionality, price, brand name, fashion trends, ecological aspect, origin of product, etc.), set of recommendations for improving sustainability in fashion (fair trade, recycling, supporting the local producers, additional taxation of environmentally unfriendly products, innovations, customization of products, second-hand and vintage clothing, clothing rental services, DIY fashion (Do it yourself), information about environmental load of each product) and so on. Based on previous scientific studies, in this research such customers' sustainable fashion perception main aspects as customers' interest in sustainable fashion, sustainable fashion features and garment's characteristics were selected for evaluation.

\section{Research Methodology}

Methodolo. Survey (structured questionnaire) and multiple criteria assessment method were applied to evaluate the perception of sustainable fashion among Lithuanian customers.

Scientists and business practitioners of sustainable fashion often use survey (structured questionnaire) to define the problem, test hypotheses and measure the impact of variables (Niinimäki, 2011). This research method is an efficient and practical instrument to collect and analyse large amount of data related to 
customers' sustainable fashion perception. To assure the quality of response the survey consists of closed-ended structured questions and related to the evaluation of such aspects: an interest in sustainable fashion, and a willingness to spend more money in sustainable fashion; a rating of spectrum of factors influencing product purchase decision (need, fit, suitability, colour, quality, materials, multifunctionality, price, brand name, fashion trends, environmental friendly, ecological aspect, origin of product); a rating of problems solutions of unsustainability in fashion (Fair-trade, recycling, supporting the local producers, additional taxation of environmentally unfriendly products, innovations in textile industry, customization of products, second-hand and vintage clothing, clothing rental services, DIY fashion, more information about environmental load of each product). A structured questionnaire was created on Smartsurvey platform, and shared via social media and emails. An online survey (structured questionnaire) was held in two languages (English and Lithuanian) to segment results into two groups: Lithuanian and International (European). The research was conducted in September-November, 2019. In the international version mostly participated respondents from Poland, Germany, Portugal, Spain, and the United Kingdom. In Lithuanian version took part in respondents residing in Lithuania and abroad.

The results of survey (structured questionnaire) were evaluated using a multiple criteria assessment method. This method was chosen to evaluate the complexity of the factors that influence customers' sustainable fashion perception. Using the multiple criteria method allows quantitatively to evaluate complicated phenomenon expressed by most variables (Raudeliūnienè, Meidutè, and Martinaitis, 2012; Xu, 2012; Raudeliūnienè, Davidavičienè, and Petrusevičius, 2018; Raudeliūnienè, Davidavičienè, Tvaronavičienè, and Jonuška, 2018). The multiple criteria method includes set of instruments and tools in order to evaluate research object and form decisions.

In this study, a Chi-square test was conducted to measure the consistency of respondents' opinions. The test consists of such steps: calculation of the sum of ranks e_i, the sum of each participant's given ranks, the sum of all values, the average value of criteria, the sum of squared deviation, the maximum value of sum of squared deviation, a coefficient of Concordance, the significance of coefficient of Concordance (the value is compared with the one in the Chisquare including 0.05 degrees of freedom in this case), the average value of each criterion, and the values normalization (using Euclidean normalization) (Table 2). 
Table 2: Evaluation steps of customers' sustainable fashion perception (created according to Raudeliūnienè, Meidutè, and Martinaitis, 2012; Xu, 2012;

Raudeliūnienè, Davidavičienè, and Petrusevičius, 2018; Raudeliūnienė,

Davidavičienė, Tvaronavičienè, and Jonuška, 2018)

\begin{tabular}{|c|c|}
\hline The evaluative aspect & Formula \\
\hline The average value of criteria & $\begin{array}{c}\overline{\mathrm{e}}=\frac{e_{\mathrm{i}}}{n} \\
\text { where: }{ }^{n}-\text { number of criteria }\end{array}$ \\
\hline The sum of squared deviation & $S=\sum i(e i-\theta)^{2}$ \\
\hline $\begin{array}{c}\text { The maximum value of sum of } \\
\text { squared deviation }\end{array}$ & $\begin{array}{c}\operatorname{Smax}=\frac{r^{2} m\left(m^{2}-1\right)}{12} \\
\text { where: }{ }^{r}-\text { number of participants, }{ }^{m} \text { criteria }\end{array}$ \\
\hline Coefficient of Concordance & $W=\frac{S}{S_{\max }}$ \\
\hline $\begin{array}{l}\text { The significance of coefficient of } \\
\text { Concordance }\end{array}$ & $x^{2}=W \cdot r(m-1)$ \\
\hline $\begin{array}{l}\text { Values normalization using } \\
\text { Euclidean normalization }\end{array}$ & $x$ norm $=\frac{x}{\sqrt{\sum^{2} 2}}$ \\
\hline
\end{tabular}

\section{Research Results and Discussion}

To evaluate sustainable fashion perception among Lithuanian customers and measure how it differs from the perception of sustainable fashion in other Europe Union countries an international survey was conducted. A separate analysis of responses provided a possibility to compare the results and make conclusions on similarities and differences between the two versions.

In International and Lithuanian versions of the survey took part 31 and 37 respondents respectively, in total 68 respondents. The first step was to measure the level of interest in a sustainable fashion. Research results present that there is a higher interest in sustainable fashion in Lithuania, 57\% to $45 \%$ in Europe. However, considering the answer option "Rather yes than no" as a positive one, the results are almost the same $-73 \%$ to $71 \%$ accordingly. The number of customers not interested in sustainable fashion is equal for both versions, $24 \%$ and $23 \%$ respectively (Figure 1 ).

For further analysis, respondents' answers have been filtered in a few steps and target groups were defined. Firstly, only interested in sustainable fashion participants have been selected. Then, answers on the question about readiness to spend more money in sustainable fashion were revised and for the 
International version, 8 most valuable survey participants (Group 1) were selected. In the Lithuanian version eventually greater number of respondents were interested in sustainable fashion, so the selection process included an additional step. Answers on the question "How often do you think about the sustainability of your purchasing decisions?" have been revised, and a group of 9 most important respondents (Group 2) was defined.

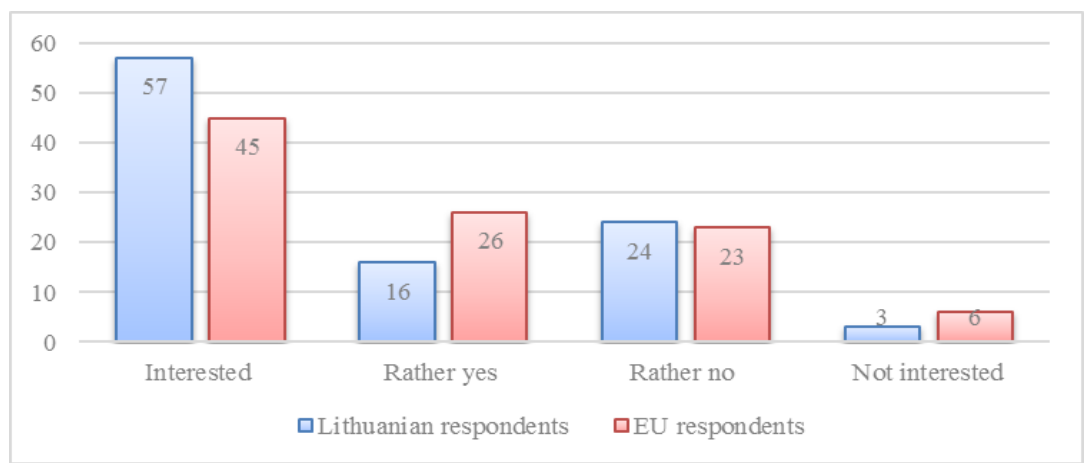

Fig. 1: Customers' interest in sustainable fashion (\%) (created by the authors)

Research results show that the willingness to spend more money in sustainable fashion is more than $70 \%$ in both groups: $73 \%$ (Lithuanian respondents) and $76 \%$ (International respondents) (Table 3).

Table 3: Measurement of the willingness to spend more money in sustainable fashion by number of Lithuanian (L) and International (I) respondents and value (created by the authors)

\begin{tabular}{|c|c|c|c|c|c|c|c|c|c|c|}
\hline \multirow{2}{*}{$\begin{array}{c}\text { Scale/ } \\
\text { No of } \\
\text { respondents }\end{array}$} & \multicolumn{2}{|c|}{ Up to $5 \%$} & \multicolumn{2}{|c|}{ Up to $10 \%$} & \multicolumn{2}{|c|}{ Up to $15 \%$} & \multicolumn{2}{|c|}{ Up to $20 \%$} & \multicolumn{2}{|c|}{ SUM } \\
\hline & $\mathbf{L}$ & I & $\mathbf{L}$ & I & $\mathbf{L}$ & I & $\mathbf{L}$ & I & $\mathbf{L}$ & I \\
\hline Yes & 2 & 2 & 7 & 4 & 7 & 6 & 5 & 2 & 21 & 14 \\
\hline Rather Yes & 0 & 2 & 5 & 3 & 0 & 2 & 1 & 1 & 6 & 8 \\
\hline Rather No & 0 & 1 & 3 & 2 & 0 & 1 & 1 & 0 & 4 & 4 \\
\hline No & 1 & 1 & 1 & 1 & 2 & 1 & 2 & 0 & 6 & 3 \\
\hline SUM & 3 & 6 & 16 & 10 & 9 & 10 & 9 & 3 & 37 & 29 \\
\hline Value & \multicolumn{2}{|c|}{ Up to $5 \%$} & \multicolumn{2}{|c|}{ Up to $10 \%$} & \multicolumn{2}{|c|}{ Up to $15 \%$} & \multicolumn{2}{|c|}{ Up to $20 \%$} & \multicolumn{2}{|c|}{ SUM } \\
\hline Yes & 0.09524 & 0.14286 & 0.33333 & 0.28571 & 0.33333 & 0.42857 & 0.23810 & 0.14286 & 1 & 1 \\
\hline Rather Yes & 0.00000 & 0.25000 & 0.83333 & 0.37500 & 0.00000 & 0.25000 & 0.16667 & 0.12500 & 1 & 1 \\
\hline Rather No & 0.0000 & 0.25000 & 0.7500 & 0.50000 & 0.0000 & 0.25000 & 0.2500 & 0.00000 & 1 & 1 \\
\hline No & 0.16667 & 0.33333 & 0.16667 & 0.33333 & 0.33333 & 0.33333 & 0.33333 & 0.00000 & 1 & 1 \\
\hline
\end{tabular}


In the next step, answers of two groups on the questions related to important features of a garment during purchase decision and important features of sustainable fashion were analysed using the Chi-square test. The value of each feature was calculated and normalized applying Euclidean normalization, then the features were ranked. The research results show that the opinions of Group 1 on both questions are inconsistent, while the opinions of Group 2 are consistent for one of the questions (Table 4 and 5).

Table 4: Measurement of evaluation of garment's particular features (International respondents)

\begin{tabular}{|c|c|c|c|c|c|}
\hline $\begin{array}{l}\text { Respondents } \\
\text { / Criteria }\end{array}$ & $\begin{array}{c}\text { Fit, } \\
\text { suitability }\end{array}$ & Colour & Quality & $\begin{array}{c}\text { Multifunctio } \\
\text { nality }\end{array}$ & Price \\
\hline 3 & 10 & 9 & 5 & 8 & 7 \\
\hline 4 & 4 & 10 & 9 & 8 & 7 \\
\hline 12 & 10 & 3 & 5 & 6 & 7 \\
\hline 15 & 9 & 3 & 7 & 5 & 6 \\
\hline 16 & 3 & 8 & 2 & 6 & 5 \\
\hline 22 & 7 & 9 & 10 & 1 & 2 \\
\hline 23 & 3 & 7 & 9 & 4 & 8 \\
\hline 31 & 9 & 7 & 10 & 1 & 6 \\
\hline ei & 55 & 56 & 57 & 39 & 48 \\
\hline $\mathrm{S}$ & 121 & 144 & 169 & 25 & 16 \\
\hline$\overline{\mathrm{e}}$ & & 44 & & & \\
\hline Smax & & 5280 & & & \\
\hline $\mathrm{W}$ & & 0.2299 & & & \\
\hline $\mathrm{X} 2$ & & 16.55454545 & Chi Square & 16.919 & \\
\hline Wght & 6.875 & 7 & 7.125 & 4.875 & 6 \\
\hline Wght norm & 0.125 & 0.127272727 & 0.129545455 & 0.088636364 & 0.109090909 \\
\hline Place & 3 & 2 & 1 & 7 & 5 \\
\hline Brand name & $\begin{array}{l}\text { Need in new } \\
\text { clothes }\end{array}$ & $\begin{array}{c}\text { Current } \\
\text { fashion trends }\end{array}$ & $\begin{array}{l}\text { Environmenta } \\
\text { lly friendly }\end{array}$ & $\begin{array}{l}\text { Product } \\
\text { Origin }\end{array}$ & Sum \\
\hline 2 & 4 & 1 & 6 & 3 & 55 \\
\hline 2 & 6 & 1 & 5 & 3 & 55 \\
\hline 2 & 4 & 1 & 9 & 8 & 55 \\
\hline 2 & 10 & 1 & 8 & 4 & 55 \\
\hline 9 & 1 & 10 & 4 & 7 & 55 \\
\hline 8 & 3 & 4 & 6 & 5 & 55 \\
\hline 2 & 10 & 1 & 5 & 6 & 55 \\
\hline 4 & 5 & 3 & 8 & 2 & 55 \\
\hline 31 & 43 & 22 & 51 & 38 & 440 \\
\hline 169 & 1 & 484 & 49 & 36 & 1214 \\
\hline & & & & & \\
\hline & & & & & \\
\hline & & & & & \\
\hline 3.875 & 5.375 & 2.75 & 6.375 & 4.75 & 55 \\
\hline 0.070454545 & $\begin{array}{c}0.09772727 \\
3\end{array}$ & 0.05 & 0.115909091 & 0.086363636 & 1 \\
\hline 9 & 6 & 10 & 4 & 8 & \\
\hline
\end{tabular}


Table 5: Measurement of evaluation of garment's particular features (Lithuanian respondents)

\begin{tabular}{|c|c|c|c|c|c|}
\hline $\begin{array}{c}\text { Respondents/ } \\
\text { Criteria }\end{array}$ & $\begin{array}{c}\text { Fit, } \\
\text { suitabilit } \\
\mathbf{y} \\
\end{array}$ & Colour & Quality & $\begin{array}{c}\text { Multifunctio } \\
\text { nality }\end{array}$ & Price \\
\hline 1 & 9 & 10 & 6 & 5 & 7 \\
\hline 3 & 7 & 6 & 9 & 4 & 8 \\
\hline 7 & 4 & 3 & 2 & 7 & 5 \\
\hline 10 & 10 & 9 & 7 & 8 & 2 \\
\hline 12 & 8 & 10 & 9 & 2 & 7 \\
\hline 16 & 3 & 2 & 5 & 8 & 4 \\
\hline 25 & 8 & 6 & 9 & 10 & 3 \\
\hline 27 & 6 & 7 & 10 & 3 & 8 \\
\hline 37 & 8 & 6 & 10 & 4 & 5 \\
\hline ei & 63 & 59 & 67 & 51 & 49 \\
\hline $\mathrm{S}$ & 182.25 & 90.25 & 306.25 & 2.25 & 0.25 \\
\hline$\overline{\mathrm{E}}$ & & 49.5 & & & \\
\hline Smax & & 6682.5 & & & \\
\hline $\mathrm{W}$ & & 0.210774411 & & & \\
\hline $\mathrm{X} 2$ & & 17.07272727 & Chi Square & 16.919 & \\
\hline Wght. & 7 & 6.555555556 & 7.444444444 & 5.666666667 & $\begin{array}{c}5.44444444 \\
4 \\
\end{array}$ \\
\hline $\begin{array}{l}\text { Wg. } \\
\text { norm }\end{array}$ & $\begin{array}{c}0.127272 \\
727\end{array}$ & 0.119191919 & 0.135353535 & 0.103030303 & $\begin{array}{c}0.09898989 \\
9\end{array}$ \\
\hline Place & 2 & 3 & 1 & 4 & 5 \\
\hline Brand name & $\begin{array}{l}\text { Need in } \\
\text { new } \\
\text { clothes }\end{array}$ & $\begin{array}{c}\text { Current } \\
\text { fashion trends }\end{array}$ & $\begin{array}{l}\text { Environmenta } \\
\text { lly friendly }\end{array}$ & $\begin{array}{c}\text { Product } \\
\text { Origin }\end{array}$ & Sum \\
\hline 1 & 4 & 2 & 8 & 3 & 55 \\
\hline 2 & 10 & 3 & 5 & 1 & 55 \\
\hline 9 & 1 & 8 & 6 & 10 & 55 \\
\hline 1 & 3 & 6 & 5 & 4 & 55 \\
\hline 1 & 4 & 3 & 6 & 5 & 55 \\
\hline 10 & 1 & 7 & 6 & 9 & 55 \\
\hline 1 & 5 & 4 & 7 & 2 & 55 \\
\hline 2 & 5 & 1 & 9 & 4 & 55 \\
\hline 3 & 9 & 1 & 7 & 2 & 55 \\
\hline 30 & 42 & 35 & 59 & 40 & 495 \\
\hline 380.25 & 56.25 & 210.25 & 90.25 & 90.25 & 1408.5 \\
\hline & & & & & \\
\hline & & & & & \\
\hline 3.333333333 & $\begin{array}{c}4.666666 \\
667\end{array}$ & 3.888888889 & 6.555555556 & 4.444444444 & 55 \\
\hline 0.060606061 & $\begin{array}{c}0.084848 \\
485\end{array}$ & 0.070707071 & 0.119191919 & 0.080808081 & 1 \\
\hline 9 & 6 & 8 & 3 & 7 & \\
\hline
\end{tabular}

The Group 1 ranked important features of a garment in the next order: 1 quality (0.1295); 2 - colour (0.1272); 3 - fit, suitability (0.1250); 4 - 
environmentally friendly, ecological aspects $(0.1159) ; 5$ - price $(0.1090) ; 6$ actual need in new clothes (0.0972); 7 - multifunctionality $(0.0886) ; 8$ - product origin (0.0863); 9 - brand name $(0.0704)$; and 10 - current fashion trends (0.0500) (Table 6).

Table 6: Measurement of particular features of sustainable fashion (International respondents)

\begin{tabular}{|c|c|c|c|c|c|}
\hline $\begin{array}{c}\text { Respondents / } \\
\text { Criteria }\end{array}$ & Fair trade & Recycling & $\begin{array}{c}\text { Supporting } \\
\text { local } \\
\text { producers }\end{array}$ & $\begin{array}{l}\text { Additional } \\
\text { taxation }\end{array}$ & Innovations \\
\hline 3 & 6 & 10 & 8 & 4 & 9 \\
\hline 4 & 8 & 6 & 7 & 1 & 10 \\
\hline 12 & 8 & 7 & 6 & 9 & 4 \\
\hline 15 & 10 & 7 & 6 & 1 & 5 \\
\hline 16 & 4 & 2 & 6 & 1 & 5 \\
\hline 22 & 6 & 9 & 7 & 10 & 4 \\
\hline 23 & 4 & 3 & 6 & 1 & 7 \\
\hline 31 & 5 & 7 & 10 & 6 & 8 \\
\hline$e_{i}$ & 51 & 51 & 56 & 33 & 52 \\
\hline$S$ & 49 & 49 & 144 & 121 & 64 \\
\hline $\bar{e}$ & & 44 & & & \\
\hline Smax & & 5280 & & & \\
\hline$W$ & & 0.18902 & & & \\
\hline$X^{2}$ & & 13.60909091 & Chi Square & 16.919 & \\
\hline Wght & 6.375 & 6.375 & 7 & 4.125 & 6.5 \\
\hline Wght norm & $\begin{array}{c}0.1159090 \\
91 \\
\end{array}$ & 0.115909091 & 0.127272727 & 0.075 & 0.118181818 \\
\hline Place & 3 & 3 & 1 & 6 & 2 \\
\hline Customization & $\begin{array}{c}\text { Second- } \\
\text { hand and } \\
\text { vintage cl. }\end{array}$ & $\begin{array}{l}\text { Clothing } \\
\text { rental } \\
\text { services }\end{array}$ & DIY fashion & Information & Sum \\
\hline 3 & 7 & 2 & 5 & 1 & 55 \\
\hline 3 & 4 & 2 & 9 & 5 & 55 \\
\hline 3 & 5 & 1 & 2 & 10 & 55 \\
\hline 4 & 8 & 2 & 9 & 3 & 55 \\
\hline 7 & 8 & 10 & 9 & 3 & 55 \\
\hline 2 & 5 & 3 & 1 & 8 & 55 \\
\hline 8 & 10 & 2 & 9 & 5 & 55 \\
\hline 3 & 4 & 2 & 1 & 9 & 55 \\
\hline 33 & 51 & 24 & 45 & 44 & 440 \\
\hline 121 & 49 & 400 & 1 & 0 & 998 \\
\hline & & & & & \\
\hline & & & & & \\
\hline & & & & & \\
\hline & & & & & \\
\hline 4.125 & 6.375 & 3 & 5.625 & 5.5 & 55 \\
\hline 0.075 & $\begin{array}{c}0.1159090 \\
91 \\
\end{array}$ & 0.054545455 & 0.102272727 & 0.1 & 1 \\
\hline 6 & 3 & 7 & 4 & 5 & \\
\hline
\end{tabular}


Table 7. Measurement of particular features of sustainable fashion (Lithuanian respondents)

\begin{tabular}{|c|c|c|c|c|c|}
\hline $\begin{array}{c}\text { Respondents / } \\
\text { Criteria }\end{array}$ & $\begin{array}{l}\text { Fair } \\
\text { trade }\end{array}$ & Recycling & $\begin{array}{l}\text { Supporting } \\
\text { local } \\
\text { producers }\end{array}$ & $\begin{array}{c}\text { Additional } \\
\text { taxation }\end{array}$ & Innovations \\
\hline 1 & 4 & 9 & 5 & 1 & 6 \\
\hline 3 & 10 & 5 & 3 & 9 & 8 \\
\hline 7 & 1 & 6 & 3 & 4 & 5 \\
\hline 10 & 10 & 9 & 4 & 7 & 1 \\
\hline 12 & 7 & 8 & 5 & 10 & 4 \\
\hline 16 & 2 & 4 & 6 & 5 & 1 \\
\hline 25 & 8 & 1 & 3 & 4 & 10 \\
\hline 27 & 9 & 8 & 2 & 10 & 6 \\
\hline 37 & 10 & 8 & 1 & 3 & 9 \\
\hline$e_{i}$ & 61 & 58 & 32 & 53 & 50 \\
\hline$S$ & 132.25 & 72.25 & 306.25 & 12.25 & 0.25 \\
\hline $\bar{e}$ & $\begin{aligned} \mathrm{e} & =495 / 10 \\
& =49,5\end{aligned}$ & 49.5 & & & \\
\hline Smax & & 6682.5 & & & \\
\hline$W$ & & 0.1557052 & & & \\
\hline$X^{2}$ & & 12.61212121 & Chi Square & 16.919 & \\
\hline Wght & $\begin{array}{c}6.777777 \\
778\end{array}$ & 6.444444444 & 3.555555556 & 5.888888889 & $\begin{array}{c}5.55555555 \\
6\end{array}$ \\
\hline Wght norm & $\begin{array}{c}0.123232 \\
323\end{array}$ & 0.117171717 & 0.064646465 & 0.107070707 & $\begin{array}{c}0.10101010 \\
1\end{array}$ \\
\hline Place & 2 & 3 & 10 & 4 & 6 \\
\hline Customization & $\begin{array}{l}\text { Second- } \\
\text { hand and } \\
\text { vintage } \\
\text { cl. }\end{array}$ & $\begin{array}{c}\text { Clothing } \\
\text { rental services }\end{array}$ & DIY fashion & Information & Sum \\
\hline 8 & 7 & 3 & 2 & 10 & 55 \\
\hline 7 & 6 & 1 & 2 & 4 & 55 \\
\hline 2 & 9 & 10 & 8 & 7 & 55 \\
\hline 2 & 3 & 5 & 6 & 8 & 55 \\
\hline 2 & 6 & 3 & 1 & 9 & 55 \\
\hline 8 & 3 & 9 & 10 & 7 & 55 \\
\hline 2 & 6 & 7 & 5 & 9 & 55 \\
\hline 3 & 7 & 1 & 4 & 5 & 55 \\
\hline 2 & 4 & 5 & 6 & 7 & 55 \\
\hline 36 & 51 & 44 & 44 & 66 & 495 \\
\hline 182.25 & 2.25 & 30.25 & 30.25 & 272.25 & 1040.5 \\
\hline & & & & & \\
\hline & & & & & \\
\hline 4 & $\begin{array}{c}5.666666 \\
667\end{array}$ & 4.888888889 & 4.888888889 & 7.333333333 & 55 \\
\hline 0.072727273 & $\begin{array}{c}0.103030 \\
303\end{array}$ & 0.088888889 & 0.088888889 & 0.133333333 & 1 \\
\hline 9 & 5 & 7 & 8 & 1 & \\
\hline
\end{tabular}


The Group 2 ranked the same features in this order: 1 - quality $(0.1353) ; 2$ fit, suitability (0.1272); 3 - colour (0.1191); 3 - environmentally friendly, ecological aspects $(0.1191) ; 4-$ multifunctionality $(0.1030) ; 5-$ price $(0.0989) ; 6$ - actual need in new clothes (0.0848); 7 - product origin $(0.0808) ; 8$ - current fashion trends (0.0707); and 9 - brand name (0.0606) (Table 5).

Regular consumer evaluates three features of a garment as most important during purchase decision: quality of the garment and materials used, how it suits the consumer and its particular details like colour, silhouette, and design. These results correspond with the results of analogical surveys held in other countries. Two groups also had highly evaluated environmental features of the item. This means that sustainable features of clothing bring additional value to the consumer during purchase decision making. Surprisingly, the brand and current fashion trends seem to be least important for the consumer.

The selected features of sustainable fashion were ranked by Group 1 in the next order: 1 - supporting local producers (0.1272); 2 - innovations $(0.1181) ; 3$ fair trade (0.1159); 3 - recycling (0.1159); 3 - second hand and vintage clothing (0.1059); 4 - DIY fashion ( (0.1022); 5 - providing more information about environmental load of each product (0.1000); 6 - customization (0.0750); 6 additional taxation of environmentally unfriendly products $(0.0750) ; 7$ - clothing rental services (0.0545) (Table 6).

The Group 2 ranked the features in the order: 1 - providing more information about environmental load of each product $(0.1333) ; 2$ - fair trade (0.1232); 3 - recycling $(0.1171) ; 4$ - additional taxation of environmentally unfriendly products $(0.1070) ; 5$ - second hand and vintage clothing $(0.1030) ; 6$ - innovations (0.1010); 7 - DIY fashion (0.0888); 7 - clothing rental services $(0.0888) ; 8$ - customization $(0.0727) ; 9$ - supporting local producers $(0.0646)$ (Table 7).

The results of the Lithuanian survey present that providing clear information about the product is perceived as highly sustainable. Additional information about the item, its production features and maintenance instructions provided via proper labelling, packaging and brands' communication can influence the purchase decision and further in-use time of clothing. However, the international survey presents a different ranking. The first places were given to local production and innovations. Local production is often referred to as a feature of sustainability because it combines all three main aspects of sustainability: economic, social and environmental. Economic and social sustainability are important on the micro and macro levels and can be described as working places, growing the economy and fair wages, while the environmental sustainability can be explained by weaver transportation costs 
and energy consumption. Innovations in sustainable fashion can be used in all field from raw materials sourcing to production and retail. These aspects make the negative impact of human activity less harmful for nature, but also help to create clothing of better quality, adapted to a particular consumer.

Both groups highly evaluated fair trade and recycling features of sustainable fashion. These two features are familiar to the regular consumer, because both terms have been used in marketing campaigns of different brands. Also, fair trade is widely used in the food industry, so a consumer can simply transfer its meaning onto clothing.

In sum, the evaluation of particular features of sustainable fashion is different for Lithuanian and International respondents that can be caused by multiple factors. However, features of clothing important for the purchase decision have been ranked similarly. Also, Lithuanian customers display a greater interest in a sustainable fashion.

\section{Conclusions}

The lack of corporate social responsibility of fashion industry and irresponsible consumer behaviour has created the preconditions for such research object as customers' sustainable fashion perception. Sustainable fashion can be defined as eco-designed fashion products, relationship with clothing and a capacity to be ethical when buying and wearing clothing that can improve sustainable apparel consumption.

Consumers' perception of sustainable fashion is affected by various factors that were analysed in this study: customers' interest in sustainable fashion, variety of factors influencing product purchase decision (need, fit, colour, quality, multifunctionality, price, brand name, fashion trends, ecological aspect, origin of product) and solutions in unsustainability in fashion (fair trade, recycling, supporting the local producers, additional taxation of environmentally unfriendly products, innovations in textile industry, customization of products, second-hand and vintage clothing, clothing rental services, DIY fashion, information about environmental load of each product).

Research results show that there are minor differences in consumers' perception of the important features of the garment during purchase decision making. The three most important features were the same for both Lithuanian and International respondents of the survey: quality, fit and suitability, and colour. However, the perception of features of sustainable fashion in Lithuania differs from that in Europe in general.

The results of the analysis show that the participants of the international survey evaluated the support of local production, innovations, fair trade and 
recycling as the most important features for sustainable fashion. While the Lithuanian respondents perceive providing information about the product, fair trade, recycling and additional taxation of environmentally unfriendly products as highly efficient features. Both groups similarly evaluated second hand and vintage options and gave less acknowledgment of customization and clothing rental services.

The study is pilot due to such research limitations as a small sample size and narrow geographical region. In total 68 respondents from Lithuania and abroad participated in an online survey.

\section{References}

Acs, Z.J, Desai, S. \& Hessels, J. (2008). Entrepreneurship, economic development and institutions. Small Business Economics, 31(3), 219-234.

Ajzen, I. \& Fishbein, M. (1980). Understanding Attitudes and Predicting Social Behaviour. Prentice Hall, Englewood Cliffs. New Jersey.

Alajmi, M. A. (2019). The impact of E-portfolio uses on the development of professional standards and life skills of students in the Faculty of Education at Princess NouraBint Abdul Rahman University. Entrepreneurship and Sustainability Issues, 6(4), 1714-1735. http://doi.org/10.9770/jesi.2019.6.4(12)

Ashworth, C. J. (2012). Marketing and organisational development in e-SMEs: understanding survival and sustainability in growth-oriented and comfort-zone pure-play enterprises in the fashion retail industry. International Entrepreneurship and Management Journal, 8(2), 165-201. https://doi.org/10.1007/s11365-011-0171-6

Athwal, N., Wells, V. K., Carrigan, M., \& Henninger, C. E. (2019). Sustainable luxury marketing: A Synthesis and research agenda. International Journal of Management Reviews, 21(4), 405-426. https://doi.org/10.1111/ijmr.12195

Clarke, J. S., \& Holt, R. (2016). Vivienne Westwood and the ethics of consuming fashion. Journal of Management Inquiry, 25(2), 199-213. https://doi.org/10.1177/1056492615592969

Davidavičienė, V., Davidavičius, S. \& Tamošiūnienè, R. (2019). B2C marketing communication in social media: fashion industry specifics. International Conference on Creative Business for Smart and Sustainable Growth, CreBUS, 3 (1-4), 18-21. https://doi.org/10.1109/CREBUS.2019.8840067

Diddi, S., \& Yan, R.-N. (2019). Consumer perceptions related to clothing repair and community mending events: a circular economy perspective. Sustainability, 11(19), 1-17. https://doi.org/10.3390/su11195306 
Garcia-Torres, S., Rey-Garcia, M., Albareda-Vivo, L. (2017). Effective disclosure in the fast-fashion industry: from sustainability reporting to action. Sustainability, 9(12), 1-27. https://doi.org/10.3390/su9122256

Geiger, S. M., \& Keller, J. (2018). Shopping for clothes and sensitivity to the suffering of others: The role of compassion and values in sustainable fashion consumption. Environment and Behavior, 50(10), 1119-1144. https://doi.org/10.1177/0013916517732109

Goworek, H., Fisher, T., Cooper, T., Woodward, S., \& Hiller, A. (2012). The sustainable clothing market: An evaluation of potential strategies for UK retailers. International Journal of Retail \& Distribution Management, 40(12), 935-955. https://doi.org/10.1108/09590551211274937

Gupta, S., Gwozdz, W., \& Gentry, J. (2019). The role of style versus fashion orientation on sustainable apparel consumption. Journal of Macromarketing, 39(2), 188-207. https://doi.org/10.1177/0276146719835283

Hedegård, L., Gustafsson, E., \& Paras, M. K. (2019). Management of sustainable fashion retail based on reuse - A struggle with multiple logics. International Review of Retail, Distribution and Consumer Research, 1-20. https://doi.org/10.1080/09593969.2019.1667855

Karimi, A. M. R., Ahmad, E., Akbar, S. \& Davidavičienė, V. (2018). The effect of customer equity drivers on word-of-mouth behavior with mediating role of customer loyalty and purchase intention. Engineering Economics, 29(2), 236246. https://doi.org/10.5755/j01.ee.29.2.17718

Lueg, R., Pedersen, M. M. \& Clemmensen, S. N. (2015). The role of corporate sustainability in a low-cost business model - A case study in the Scandinavian fashion industry. Business Strategy and the Environment, 24(5), 344-359. https://doi.org/10.1002/bse.1825

Luque, A. \& Herrero-Garcia, N. (2019). How corporate social (ir)responsibility in the textile sector is defined, and its impact on ethical sustainability: An analysis of 133 concepts. Corporate Social Responsibility and Environmental Management, 26(6), 1285-1306. https://doi.org/10.1002/csr.1747

McIntyre, M. P. (2019). Shame, blame, and passion: Affects of (un)sustainable wardrobes. Fashion Theory, 1-22.

https://doi.org/10.1080/1362704X.2019.1676506

McKeown, C., \& Shearer, L. (2019). Taking sustainable fashion mainstream: Social media and the institutional celebrity entrepreneur. Journal of Consumer Behaviour, 1-9. https://doi.org/10.1002/cb.1780. 
McNeill, L., \& Venter, B. (2019). Identity, self-concept and young women's engagement with collaborative, sustainable fashion consumption models.

International Journal of Consumer Studies, 43(4), 368-378.

https://doi.org/10.1111/ijcs.12516

Niinimäki, K. (2011). From Disposable to Sustainable: the Complex Interplay between Design and Consumption of Textiles and Clothing. Aalto University, Aalto University publication series Doctoral Dissertations. 294 p.

Perez, A., \& Lonsdale, M. (2018). Garment label design and companion information to communicate fashion sustainability issues to young consumers. Visible Language, 52(3), 115-139.

Raudeliūnienė, J., Davidavičienė, V. \& Petrusevičius, R. (2018). Factors influencing knowledge retention process: case of Lithuanian Armed Forces. Technological and Economic Development of Economy, 24(3), 1104-1124. https://doi.org/10.3846/20294913.2017.1309598

Raudeliūnienė, J., Davidavičienė, V., Tvaronavičienė, M. \& Jonuška, L. (2018). Evaluation of advertising campaigns on social media networks. Sustainability, 10(4), 1-14. https://doi.org/10.3390/su10040973

Raudeliūnienè, J., Meidutè, I. \& Martinaitis, G. (2012). Evaluation system for factors affecting creativity in the Lithuanian Armed Forces. Journal of Business Economics and Management, 13(1), 148-166. https://doi.org/10.3846/16111699.2011.639797

Shaw, D. S. \& Riach, K. (2011). Embracing ethical fields: constructing consumption in the margins. European Journal of Marketing, 45(7), 1051-1067.

Wagner, M., Curteza, A., Hong, Y., Chen, Y., Thomassey, S. \& Zeng, X. (2019). A design analysis for eco-fashion style using sensory evaluation tools: Consumer perceptions of product appearance. Journal of Retailing and Consumer Services, 51, 253-262.

https://doi.org/10.1016/j.jretconser.2019.06.005

$\mathrm{Xu}, \mathrm{D}-\mathrm{L}$. (2012). An introduction and survey of the evidential reasoning approach for multiple criteria decision analysis. Annals of Operations Research, 195(1), 163-187. https://doi.org/10.1007/s10479-011-0945-9 